Shallow continental shelf and slope waters may also act as lowsalinity conduits of younger terrestrial organic matter (J.E.B., unpublished data, and ref. 18), where margins are affected significantly by rivers and estuaries. However, most of this material must also be degraded in nearshore waters or sequestered in sediments as it does not appear to comprise a significant component of open ocean $\mathrm{DOC}^{29}$ and $\mathrm{POC}_{\text {susp }}$ seaward of the shelf-slope front. The isotope signatures of DOC and $\mathrm{POC}_{\text {susp }}$ at the coastal-open ocean boundaries (that is, slope and rise waters) here indicate that this carbon has mainly a non-recent marine origin and is older than organic carbon from the North Atlantic and Pacific central gyres. If this material propagates seaward, possibly along isopycnal surfaces, it may represent a source of old DOC and POC to intermediate and deep waters of the interior ocean ${ }^{4}$.

Received 11 September 1997; accepted 21 January 1998

1. Walsh, J., Rowe, G., Iverson, R. \& McRoy, C. Biological export of shelf carbon is a sink of the global $\mathrm{CO}_{2}$ cycle. Nature 292, 196-201 (1981)

2. Smith, S. \& MacKenzie, F. The ocean as a net heterotrophic system: implications for the carbon biogeochemical cycle. Global Biogeochem. Cycles 1, 187-198 (1987).

Smith, S. \& Hollibaugh, T. Coastal metabolism and the oceanic organic carbon balance. Rev. Geophys. 31, 75-89 (1993).

. Wollast, R. in Ocean Margin Processes in Global Change (eds Mantoura, R., Martin, J.-M. \& Wollast, R.) 365-381 (Wiley, New York, 1991)

Biscaye, P., Flagg, C. \& Falkowski, P. The Shelf Edge Exchange Processes experiment, SEEP-II: an introduction to hypotheses, results and conclusions. Deep-sea Res. II 41, 231-252 (1994).

6. Walsh, J., Biscaye, P. \& Csanady, G. The 1983-1984 Shelf Edge Exchange Processes (SEEP)-I experiment: hypotheses and highlights. Cont. Shelf Res. 8, 435-456 (1988).

Williams, P. \& Druffel, E. Radiocarbon in dissolved organic matter in the central North Pacific Ocean Nature 330, 246-248 (1987).

8. Bauer, J., Williams, P. \& Druffel, E. ${ }^{14} \mathrm{C}$ activity of dissolved organic carbon fractions in the northcentral Pacific and Sargasso Sea. Nature 357, 667-670 (1992).

9. Druffel, E., Williams, P., Bauer, J. \& Ertel, J. Cycling of dissolved and particulate matter in the open ocean. J. Geophys. Res. 97, 15,639-15,659 (1992).

10. Trumbore, S. \& Druffel, E. in Role of Nonliving Organic Matter in the Earth's Carbon Cycle (Zepp, R. G. \& Sonntag, C.) 7-22 (Wiley and Sons, New York, 1995).

11. Druffel, E., Bauer, J., Williams, P., Griffin, S. \& Wolgast, D. Seasonal variability of radiocarbon in particulate organic carbon in the northeast Pacific. J. Geophys. Res. 101, 20,543-20,552 (1996).

12. Bauer, J. E., Druffel, E., Williams, P. M., Wolgast, D. \& Griffin, S. Temporal variability in dissolved organic carbon and radiocarbon in the eastern north Pacific Ocean. J. Geophys. Res. (in the press).

13. Williams, P., Robertson, K., Souter, A., Griffin, S. \& Druffel, E. Isotopic signatures $\left({ }^{14} \mathrm{C},{ }^{13} \mathrm{C},{ }^{15} \mathrm{~N}\right)$ a tracers of sources and cycling of soluble and particulate organic matter in the Santa Monica Basin. Prog. Oceanogr. 30, 253-290 (1992).

14. Smith, K., Kaufman, R. \& Baldwin, R. Coupling of near-bottom pelagic and benthic processes at abyssal depths. Limnol. Oceanogr. 39, 1101-1118 (1994).

15. Stuiver, M., Pearson, G. W. \& Braziunas, T. Radiocarbon age calibration of marine samples back to 9000 cal yr B.P. Radiocarbon 28, 980-1021 (1986).

16. Anderson, R., Rowe, G., Kemp, P., Trumbore, S. \& Biscaye, P. Carbon budget for the mid-slope depocenter of the Middle Atlantic Bight. Deep-sea Res. II 41, 669-703 (1994).

17. Churchill, J., Wirick, C., Flagg, C. \& Pietrafesa, L. Sediment resuspension over the continental shelf east of the Delmarva Peninsula. Deep-sea Res. II 41, 341-363 (1994)

18. Guo, L., Santschi, P., Cifuentes, L. \& Trumbore, S. Cycling of high-molecular-weight dissolved organi matter in the Middle Atlantic Bight as revealed by carbon isotopic $\left({ }^{13} \mathrm{C}\right.$ and $\left.{ }^{14} \mathrm{C}\right)$ signatures. Limnol. Oceanogr. 41, 1242-1252 (1996)

19. Tanaka, N., Monaghan, M. \& Turekian, K. ${ }^{14} \mathrm{C}$ balance for the Gulf of Maine, Long Island Sound and the northern Middle Atlantic Bight: evidence for the extent of the Antarctic Intermediate Water contribution. J. Mar. Res. 48, 75-87 (1990).

20. Bauer, J., Spies, R., Vogel, J., Nelson, D. \& Southon, J. Natural ${ }^{14} \mathrm{C}$ evidence of fossil carbon cycling in sediments of a marine hydrocarbon seep off California. Nature 348, 230-232 (1990).

21. Carlson, C. \& Ducklow, H. Dissolved organic carbon in the upper ocean of the central Equatorial Pacific, 1992: daily fine-scale vertical variations. Deep-sea Res. II 42, 639-656 (1995)

22. Cherrier, J., Bauer, J. \& Druffel, E. Utilization and turnover of labile dissolved organic matter by bacterial heterotrophs in eastern North Pacific waters. Mar. Ecol. Prog. Ser. 139, 267-279 (1996).

23. Hedges, J. et al. Organic ${ }^{14} \mathrm{C}$ in the Amazon River system. Science 231, 1129-1131 (1986).

24. Bauer, J., Reimers, C., Druffel, E. \& Williams, P. Isotopic constraints on carbon exchanges between deep ocean sediments and seawater. Nature 373, 686-689 (1995)

25. Jahnke, R., Reimers, C. \& Craven, D. Intensification of recycling of organic matter at the sea floor near ocean margins. Nature 348, 50-54 (1990).

26. Knauss, J. A. Introduction to Physical Oceanography (Prentice-Hall, Englewood Cliffs, NJ, 1978).

27. Carlson, C. A., Ducklow, H. W. \& Michaels, A. F. Annual flux of dissolved organic carbon from the euphotic zone in the northwestern Sargasso Sea. Nature 371, 405-408 (1994).

28. Kirchman, D., Suzuki, Y., Garside, C. \& Ducklow, H. High turnover rates of dissolved organic carbon during a spring phytoplankton bloom. Nature 352, 612-614 (1991).

29. Opsahl, S. \& Benner, R. Distribution and cycling of terrigenous dissolved organic matter in the ocean Nature 386, 480-482 (1997)

30. Vogel, J., Nelson, E. \& Southon, J. ${ }^{14} \mathrm{C}$ background levels in an accelerator mass spectrometry system. Radiocarbon 29, 323-333 (1987).

31. Stuiver, M. \& Polach, H. Discussion: reporting of ${ }^{14} \mathrm{C}$ data. Radiocarbon 19, 355-363 (1977).

Acknowledgements. We thank D. Wolgast and S. Griffin for their expert assistance in all phases of this work; K. Smith for shiptime support of our studies in the eastern N. Pacific; M. Kashgarian, J. Southon and I. Proctor of the Center for AMS at Lawrence Livermore National Laboratory for ${ }^{14} \mathrm{C}$ analyses; and J. Hedges and R. Jahnke for reviewing earlier versions of the manuscript. This work was supported by the Ocean Margins Program of the US Department of Energy and the Chemical Oceanography Program of the US NSF.

Correspondence and requests for materials should be addressed to J.E.B. (e-mail: bauer@vims.edu).

\section{The deep structure of a sea-floor hydrothermal deposit}

\author{
Robert A. Zierenberg ${ }^{1}$, Yves Fouquet ${ }^{2}$, D. J. Miller ${ }^{3}$, \\ J. M. Bahr ${ }^{4}$, P. A. Baker ${ }^{5}$, T. Bjerkgård ${ }^{6}$, C. A. Brunner ${ }^{7}$, \\ R. C. Duckworth ${ }^{8}$, R. Gable ${ }^{9}$, J. Gieskes ${ }^{10}$, \\ W. D. Goodfellow ${ }^{11}$, H. M. Gröschel-Becker ${ }^{12}$, G. Guèrin ${ }^{13}$, \\ J. Ishibashi ${ }^{14}$, G. Iturrino ${ }^{15}$, R. H. James ${ }^{16}$, \\ K. S. Lackschewitz ${ }^{17}$, L. L. Marquez ${ }^{18}$, P. Nehlig ${ }^{19}$, \\ J. M. Peter ${ }^{20}$, C. A. Rigsby ${ }^{21}$, P. Schultheiss ${ }^{22}$, \\ W. C. Shanks III ${ }^{23}$, B. R. T. Simoneit ${ }^{24}$, M. Summit ${ }^{25}$,

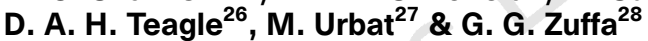

Hydrothermal circulation at the crests of mid-ocean ridges plays an important role in transferring heat from the interior of the Earth $^{1-3}$. A consequence of this hydrothermal circulation is the formation of metallic ore bodies known as volcanic-associated massive sulphide deposits. Such deposits, preserved on land, were important sources of copper for ancient civilizations and continue to provide a significant source of base metals (for example, copper and zinc $)^{4-6}$. Here we present results from Ocean Drilling Program Leg 169, which drilled through a massive sulphide deposit on the northern Juan de Fuca spreading centre and penetrated the hydrothermal feeder zone through which the metal-rich fluids reached the sea floor. We found that the style of feeder-zone mineralization changes with depth in response to changes in the pore pressure of the hydrothermal fluids and discovered a stratified zone of high-grade copper-rich replacement mineralization below the massive sulphide deposit. This copper-rich zone represents a type of mineralization not previously observed below sea-floor deposits, and may provide new targets for land-based mineral exploration.

Transects of boreholes drilled on the Ocean Drilling Program (ODP) Leg 169 defined the extent and composition of the Bent Hill massive sulphide (BHMS) deposit in Middle Valley on the northern Juan de Fuca spreading centre (Fig. 1), and is the first geometric characterization of a complete sea-floor hydrothermal system. A 500-m-deep hole through the apex of the massive sulphide deposit provided a complete vertical section of the hydrothermal system, penetrating the feeder zone, the underlying sediment column and the uppermost volcanic basement.

Middle Valley is the northern extension of the Endeavor segment of the Juan de Fuca ridge. Due to its proximity to the continent and

${ }^{1}$ Department of Geology, University of California-Davis, Davis, California 95616, USA. ${ }^{2}$ Institut Française de Recherche pour l'Exploitation de la Mer, Centre de Brest, DRO/GM, BP 7029980 Plouzane Cedex, France. ${ }^{3}$ Ocean Drilling Program, Texas A\&M Research Park, 1000 Discovery Drive, College Station, Texas 77845, USA. ${ }^{4}$ Department of Geology and Geophysics, University of Wisconsin-Madison, Madison, Wisconsin 53706, USA. ${ }^{5}$ Department of Geology, Duke University, Durham, North Carolina 27708, USA. ${ }^{6}$ Norges Geologiske Undersøkelse, 7002 Trondheim, Norway. ${ }^{7}$ Institute of Marine Sciences, University of Southern Mississippi, Stennis Space Center, Mississippi 39529, USA. ${ }^{8}$ Department of Earth Sciences, James Cook University, Townsville, Queensland 4811, Australia. ${ }^{9}$ Départment Hydrologie et Transeferts, Bureau de Recherches Géologiques et Minières, 45060 Orleans Cedex 2, France. ${ }^{10}$ Scripps Institution of Oceanography, University of California-San Diego, La Jolla, California 92093, USA. ${ }^{11}$ Geological Survey of Canada, Ottawa, Ontario K1A 0E8, Canada. ${ }^{12}$ Marine Geology and Geophysics, Rosenstiel School of Marine and Atmospheric Sciences, University of Miami, Miami, Florida 33149, USA. ${ }^{13}$ Borehole Research Group, Lamont-Doherty Earth Observatory, Columbia University, Palisades, New York 10964, USA. ${ }^{14}$ Laboratory for Earthquake Chemistry, University of Tokyo, Tokyo 113, Japan. ${ }^{15}$ Borehole Research Group, Lamont-Doherty Earth Observatory, Columbia University, Palisades, New York 10964, USA. ${ }^{16}$ Department of Geology, University of Bristol, Bristol BS8 1RJ, UK. ${ }^{17}$ Geologisch-Paläontologisches Institut, Christian-Albrechts-Universität Kiel, D24118 Kiel, Germany. ${ }^{18}$ Department of Geological Sciences, Northwestern University, Evanston, Illinois 60208, USA. ${ }^{19}$ Bureau de Recherches Géologiques et Minières, 45060 Orleans Cedex 2, France. ${ }^{20}$ Geological Survey of Canada, Ottawa, Ontario K1A 0E8, Canada. ${ }^{21}$ Department of Geology, East Carolina University, Greenville, North Carolina 27858, USA. ${ }^{22}$ GEOTEK Ltd., Northants NN11 5RD, UK. ${ }^{23}$ US Geological Survey, Denver Federal Center MS 973, Denver, Colorado 80225, USA. ${ }^{24}$ College of Oceanic and Atmospheric Sciences, Oregon State University, Corvallis, Oregon 87331, USA. ${ }^{25}$ School of Oceanography, University of Washington, Seattle, Washington 48109, USA. ${ }^{26}$ Geological Sciences, University of Michigan, Ann Arbor, Michigan 48109, USA. ${ }^{27}$ Geologisches Institut, Universität zu Köln, D-50674 Köln, Germany. ${ }^{28}$ Dipartimento di Scienze della Terra, Università di Bologna, 40127 Bologna, Italy. 
increased sediment supply during low stands of sea level caused by Pleistocene glaciation, the spreading centre is buried by continentally derived turbiditic sediments. Active extension and volcanism were contemporaneous with sediment infilling of the rift, resulting in formation of a basaltic-sill/sediment complex that forms the uppermost oceanic crust, in contrast to the extensive basaltic flows at sediment-free spreading centres ${ }^{7,8}$. High permeability in the sillsediment complex allows vigorous hydrothermal convection and has resulted in the formation of a relatively isothermal hydrothermal reservoir capped by several hundred metres of sediment with low cross-stratal permeability ${ }^{9}$. Active hydrothermal discharge (Dead Dog vent field, 'Ore Drilling Program' (ODP) mound) and massive sulphide deposits that formed at sites of recent $(<300 \mathrm{kyr}$ ago) high-temperature discharge (BHMS, ODP mound) occur within Middle Valley ${ }^{7,10}$.

The BHMS deposit is located on the south flank of a sediment hill (Bent Hill, Fig. 1) approximately $400 \mathrm{~m}$ in diameter and $50 \mathrm{~m}$ high that was elevated above the surrounding turbidite plane by the intrusion of late Pleistocene to Holocene basalts. ${ }^{7}$. The BHMS deposit is a 35-m-high mound topped by oxidized sulphide rubble and lapped by turbiditic sediment. A slightly younger massive sulphide deposit (ODP mound) is exposed $\sim 300 \mathrm{~m}$ to the south (Fig. 1), where before drilling, a single vent was discharging $264^{\circ} \mathrm{C}$ hydrothermal fluid ${ }^{11}$.

Coring of the BHMS deposit during Leg 139 (holes 856C-H) indicated that the bulk of the sulphide was deposited above the sea floor, with little evidence for sulphide veining or replacement of

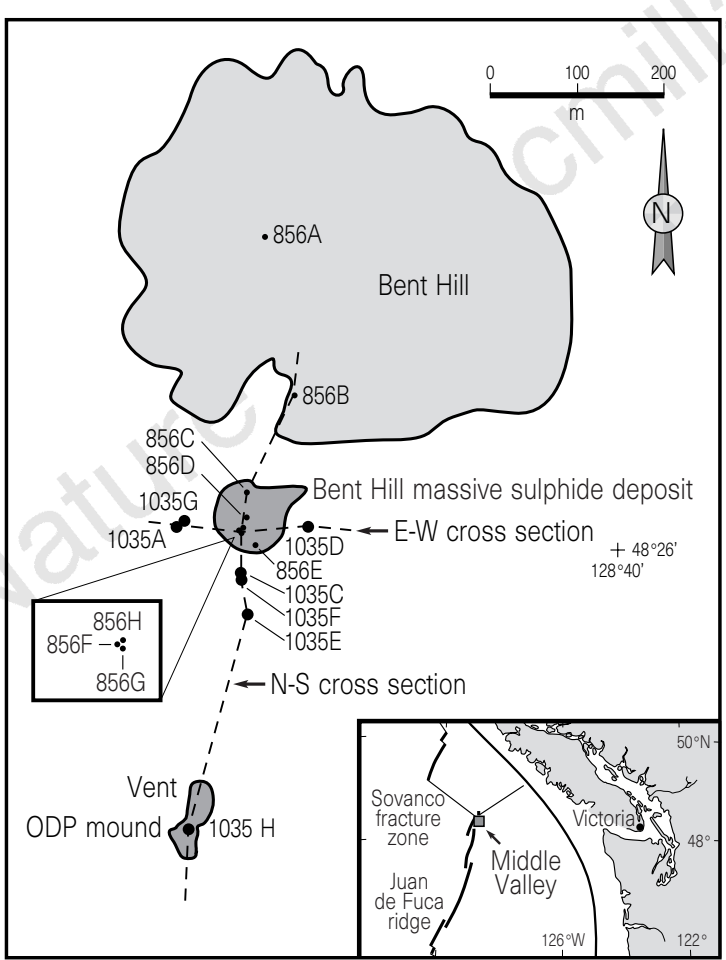

Figure 1 Location of Middle Valley (inset) and details of the study area (main figure). Two massive sulphide deposits are exposed at the sea floor to the south of Bent Hill, which is a recently uplifted sediment hill underlain by basaltic intrusions. The boundaries of Bent Hill, the Bent Hill massive sulphide deposit, and the ODP mound are interpreted from SeaMARC 1 side-scan sonar and constrained by piston coring and observations from the submersible Alvin. sediment ${ }^{7}$. The primary hydrothermal precipitate was pyrrhotite with less abundant high-temperature $\mathrm{Cu}-\mathrm{Fe}$ sulphide (isocubanite) and $\mathrm{Zn}$ sulphide (sphalerite \pm wurtzite $)^{7,12,13}$. Much of the deposit has been recrystallized to pyrite \pm magnetite, and base-metal sulphide showed textural evidence for dissolution, late-stage veining and replacement.

Hole $856 \mathrm{H}$ was re-entered on Leg 169 and drilled to a depth of $500 \mathrm{~m}$ below sea floor (m.b.s.f.). This core provides a complete vertical section through the massive sulphide deposit and underlying feeder zone, and continues through the sediment into the uppermost oceanic crust (Fig. 2).

Based on both the recovered core and downhole geophysical logging, the massive sulphide deposit has a minimum thickness of $100 \mathrm{~m}$. The massive sulphide zone is a mound with relatively steep flanks and a subhorizontal base (Fig. 2). The base of the massive sulphide lens is interpreted to be a time horizon marking the onset of vigorous hydrothermal venting. A conservative estimate of the size of the massive sulphide mound is approximately $8.8 \times 10^{6}$ tons, but this estimate does not include the significant $\mathrm{Cu}$-rich feederzone mineralization deposited below the sea floor or the mineralization associated with ODP mound, which may be of approximately equal size.

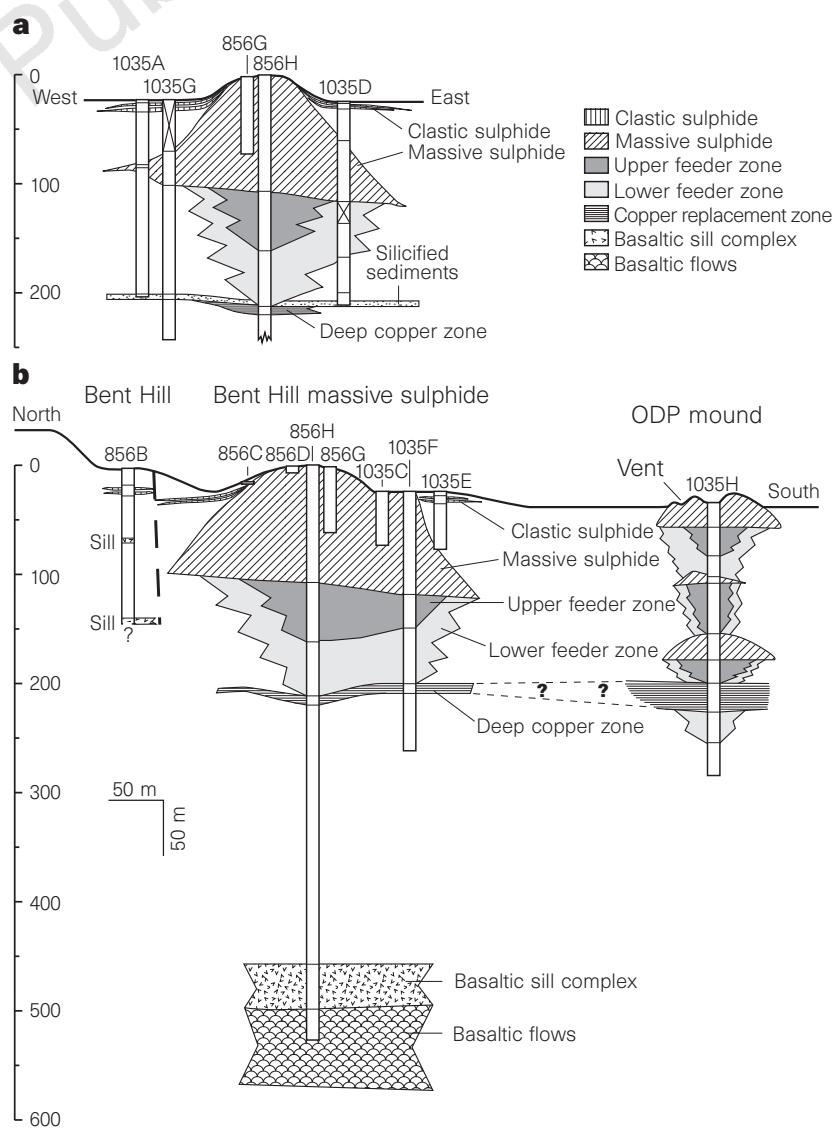

Figure 2 Interpreted cross-sectional views of the distribution of mineralized zones. This information was obtained from SeaMARC1 side-scan sonar, observations from the submersible Alvin, piston coring and drill holes from ODP legs 139 (856) and 169 (1035). a, East-west section across the Bent Hill massive sulphide deposit. b. North-South cross-section of the same area, showing the flank of the Bent Hill sediment hill, Bent Hill massive sulphide deposit and ODP mound. The interpreted structure under the ODP mound is speculative as it is constrained by a single drill hole. The hydrothermal vent at the north end of ODP mound was the only known source of hydrothermal discharge in this area before drilling. Holes $1035 \mathrm{~F}$ and $1035 \mathrm{H}$ were observed to be vigorously venting hydrothermal fluid after drilling. 
The lack of interbedded sediment indicates that BHMS deposit formed in an intense episode of sulphide mound building that was rapid relative to the rate of turbidite sedimentation. In contrast, multiple episodes of hydrothermal discharge are clearly evident in the ODP mound (Hole 1035H). Here, three stacked sequences of massive sulphide, each underlain by sediment-hosted feeder-zone mineralization, occur over a depth interval of $210 \mathrm{~m}$ (Fig. 2) indicating multiple episodes of hydrothermal activity. The lower sulphide horizons are locally coarse grained due to recrystallization by hydrothermal fluids that formed overlying sulphide lenses. The material recovered from ODP mound is much higher grade (2.9$51 \% \mathrm{Zn}, 0.12-0.62 \% \mathrm{Cu}$ ) than massive sulphide from $\mathrm{BHMS}^{14}$

One of the main accomplishments of Leg 169 was the first successful recovery of feeder-zone mineralization underlying a sea-floor massive sulphide deposit, best represented in cores from 100 to 210 m.b.s.f. in Hole $856 \mathrm{H}$ (Fig. 2). This interval has been subdivided into three subunits based on the style and intensity of mineralization and alteration. The upper $45 \mathrm{~m}$ is intensely mineralized by subvertical veins of intergrown isocubanite-chalcopyrite and pyrrhotite, with vein density decreasing downcore. The host turbidites are altered to chlorite, quartz and fine-grained rutile and titanite. Veins range from $>8 \mathrm{~cm}$ to $<1 \mathrm{~mm}$, with the thickest veins showing crack-seal textures indicative of multiple dilation due to fluid overpressure followed by mineral precipitation (Fig. 3).

The interval from 145 to 200 m.b.s.f. is less intensely veined. The relative proportion of subhorizontal veins and bedding parallel disseminated sulphide increases progressively downcore, with many subvertical veins branching off into subhorizontal sulphide impregnations of the more permeable horizons.

Core recovered between 200 to 210 m.b.s.f. is again intensely mineralized, containing up to $50 \mathrm{vol} \%$ sulphide minerals, predominantly isocubanite containing coarse exsolution lamellae of iron-rich chalcopyrite. Pyrrhotite is much less abundant than in the overlying veins and other sulphide minerals are present in only trace amounts. A representative sample of high-grade mineralization from this zone contains $16.1 \mathrm{wt} \%$ copper $^{14}$ and this subunit has been designated the deep copper zone (DCZ). In contrast to the

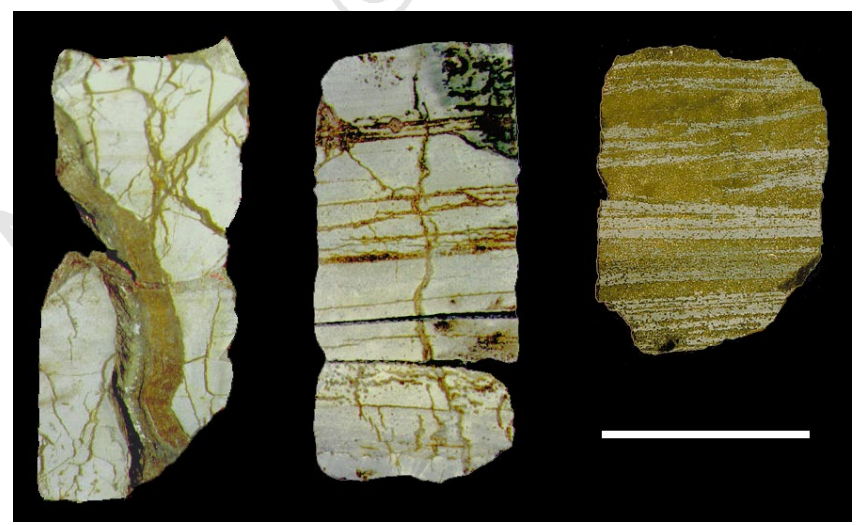

Figure 3 Sections of drill core showing mineralization of the feeder zone and the deep copper zone below the Bent Hill massive sulphide deposit. Left, predominantly vertical crack-seal veins filled with pyrrhotite and isocubanite in altered turbiditic mudstone $(856 \mathrm{H} 24 \mathrm{R}-1,50-70 \mathrm{~cm}, 134$ m.b.s.f.). This style of mineralization is characteristic of the upper feeder zone underlying the centre of the hydrothermal upflow zone. Centre, less intense feeder-zone mineralization underlying the south flank of the Bent Hill massive sulphide deposit. Mineralization consists of simple vertical and horizontal veins filled with pyrrhotite, sphalerite and isocubanite in graded fine sand to silt turbidites. Mineralization also occurs as subhorizontal replacement and disseminations along bedding planes (1035F 12R-2 43-55 cm, 112 m.b.s.f.). Right, deep copper zone mineralization in cross-laminated turbiditic sandstone. Replacement of rock by isocubanite mimics original cross-lamination; the matrix is extensively recrystallized to silvergrey coloured chlorite and quartz (856H 31R-1, 99-107 cm, 202 m.b.s.f.). overlying intervals, sulphide veining is essentially absent. Sulphide mineralization occurs as impregnations and replacement of the host sediments, and is strongly controlled by variation in the original sedimentary textures. Much of the mineralization is developed in medium- to coarse-grained, locally crossbedded, turbiditic sand, and preserves the original sedimentary structures (Fig. 3).

Feeder-zone mineralization is also well developed in Hole $1035 \mathrm{~F}$ on the south flank of the massive sulphide, but is only weakly developed under the east and west flanks of the deposit. The greater extent of sulphide feeder-zone mineralization north-south is consistent with structural control of fluid flow by rift-parallel faulting. The DCZ in Hole 1035F contains more pyrrhotite and sphalerite than in the centre of the system. High-grade $\mathrm{Cu}$-replacement mineralization $(8.0-16.6 \% \mathrm{Cu})$ also occurs below ODP mound in approximately the same stratigraphic horizon as encountered below the Bent Hill massive sulphide ${ }^{14}$. This style of high-grade, copperrich replacement mineralization below the feeder-zone was not anticipated before drilling, and similar permeable horizons, hitherto unrecognized below ancient massive sulphide deposits on land, may represent potential new exploration targets.

The transition from dominantly vertical crack-seal veins in the upper part of the feeder zone to subhorizontal mineralization controlled by sedimentary texture at the base of the feeder zone indicates that cyclic overpressure capable of fracturing the rock only occurred near the sea floor. Drilling on the east and west flanks of the deposit in holes 1035D and 1035A encountered a weakly mineralized, highly silicified mudstone horizon at the approximate depth of top of the DCZ horizon that provided an important hydrological control on the high-temperature hydrothermal system that formed the massive sulphide. During periods when the high-permeability pathways represented by the veins were sealed, fluid was forced to flow laterally into the more permeable sandy turbidite units. Conductive cooling of this ponded hydrothermal fluid facilitated silica deposition ${ }^{15}$, thus sealing the top of this interval, and the precipitation of isocubanite, which is the least soluble of the sulphide minerals that occur in this deposit.

Holes $1035 \mathrm{~F}$ and $1035 \mathrm{H}$ penetrated through the silicified zone and were observed by a television camera lowered down the drill string to be vigorously venting hydrothermal fluid. The silicified zone must still form an impermeable caprock that prevents fluids from reaching the sea floor, except when the seal is penetrated by fracturing or drilling. The intensity of hydrothermal flow out of the $25-\mathrm{cm}$ diameter borehole was sufficient to expel coarse $(>3 \mathrm{~cm})$ drill cuttings of sedimentary rock and finer fragments of massive sulphide $(5 \mathrm{~mm})$, more than $10 \mathrm{~m}$ above the sea floor. The vigour of this venting suggests that the drilling penetrated into a strongly overpressured zone.

Drilling beneath the feeder zone in Hole $856 \mathrm{H}$ ( $>210$ m.b.s.f.) penetrated lithified, but relatively unaltered metasediments to a depth of 432 m.b.s.f., then $40 \mathrm{~m}$ of interlayered basaltic sills and metasediment, and finally $30 \mathrm{~m}$ of pillow basalts, interpreted to be the top of the igneous basement. Magnetic profiles across the eastern flank of Middle Valley indicate that the transition from the weakly magnetized rocks of the sill-sediment complex to extrusive basalts occurs near Bent Hill ${ }^{16}$. It appears that the Bent Hill deposit formed near the transition from normal oceanic crust to sedimented-rift type crust, but only after a period of time sufficient for the accumulation of $350 \mathrm{~m}$ of turbidites which formed a thermal blanket and hydrological seal over the more permeable sediment-sill complex and underlying oceanic crust.

A key element in creating massive sulphide deposits as large as those drilled in Middle Valley is the extended focusing of intense hydrothermal discharge. Ridge-parallel normal faulting probably provided high-permeability pathways for channelled discharge at the sea floor in Middle Valley. Basaltic rocks from the ocean crust provided the dominant source of both heat and base metals for these sulphide deposits. However, it is the presence of a relatively 
impermeable sediment blanket in Middle Valley above very young oceanic crust that is the primary control on the style of hydrothermal circulation in this area, resulting in the formation of a seafloor mineral deposit similar in size and grade to ore deposits mined on land.

Received 1 August 1997; accepted 29 January 1998.

Wolery, T. J. \& Sleep, N. H. Hydrothermal circulation and geochemical flux at mid-ocean ridges. J. Geol. 84, 249-275 (1978).

Lister, C. R. B. in The Dynamic Environment of the Ocean Floor (eds Fanning, K. A. \& Manheim, F. T) 441-470 (Lexington Books, Lexington, 1982).

Sleep, N. H. \& Wolery, T. J. Egress of hot water from the midocean ridge hydrothermal systems: som thermal constraints. J. Geophys. Res. 96, 2375-2387 (1991).

4. Stanton, R. L. General features of the conformable "pyritic" ore-bodies. Can. Inst. Mining Metal. Trans. 63, 22-27 (1960)

5. Franklin, J. M., Lydon, J. W. \& Sangster, D. F. Volcanic-associated massive sulfide deposits. Econ. Geol. 75th Anniv. Vol. 485-627 (1981).

6. Hannington, M. D., Jonasson, I. R., Herzig, P. M. \& Petersen, S. Physical and Chemical Processes of Seafloor Mineralization at Mid-ocean Ridges 115-157 (Geophys. Monogr. 91, Am. Geophys. Union, Washington DC, 1995).

Davis, E. E. et al. Proc. ODP Init. Rep. 139, 1-1026 (1992).

8. Davis, E. E. \& Villinger, H. Tectonic and thermal structure of the Middle Valley sedimented rift, northern Juan de Fuca Ridge. Proc. ODP Init. Rep. 139, 9-41 (1992).

9. Davis, E. E. \& Fisher, A. T. On the nature and consequences of hydrothermal circulation in Middle Valley sedimented rift: inferences from geophysical and geochemical observations, Leg 139. Proc. ODP Sci. Res. 139, 695-717 (1994).

10. Goodfellow, W. D. \& Franklin, J. M. Geology, mineralogy, and chemistry of sediment-hosted clastic massive sulfides in shallow cores, Middle Valley, northern Juan de Fuca Ridge. Econ. Geol. 88, 20372068 (1994).

11. Ames, D. E., Franklin, J. M. \& Hannington, M. D. Mineralogy and geochemistry of active and inactive chimneys and massive sulfide, Middle Valley, northern Juan de Fuca Ridge: An evolving hydrotherma system. Can. Mineral. 31, 997-1024 (1993).

12. Krasnov, S., Stepanova, T. \& Stepanov, M. Chemical composition and formation of a massive sulfide deposit, Middle Valley, northern Juan de Fuca Ridge (Site 856). Proc. ODP Sci. Res. 139, 353-372 (1994).

13. Duckworth, R. C., Fallick, A. E. \& Rickard, E. Mineralogy and sulfur isotopic composition of the Middle Valley massive sulfide deposit, northern Juan de Fuca Ridge. Proc. ODP Sci. Res. 139, 373-385 (1994).

14. Fouquet, Y. et al. Middle Valley; Bent Hill area (Site 1035). Proc. ODP Init. Rep. 169 (in the press).

15. Janecky, D. J. \& Seyfried, W. E. Jr Formation of massive sulfide deposits on oceanic ridge crest incremental reaction models for mixing between hydrothermal solutions and seawater. Geochim. Cosmochim. Acta 48, 2723-2738 (1984)

16. Currie, R. G. \& Davis, E. E. Low crustal magnetization of the Middle Valley sedimented rift inferred from sea-surface magnetic anomalies. Proc. ODP Sci. Res. 139, 19-28 (1994).

Acknowledgements. We thank the staff of the Geological Survey of Canada, particularly J. M. Franklin and E. E. Davis, for sharing data and expertise on the Middle Valley area. We also thank the ODP Engineering staff, and the drilling, ship and scientific staff on-board the D/V JOIDES Resolution for their many contributions.

Correspondence and requests for materials should be addressed to R.A.Z. (e-mail: zierenberg@geology.ucdavis.edu).

\section{Megaliths and Neolithic astronomy in southern Egypt}

\section{J. McKim Malville, Fred Wendorf*, Ali A Mazar $\dagger$ \& Romauld Schild}

Department of Astrophysical and Planetary Sciences, University of Colorado, Boulder, Colorado 80309, USA

* Department of Anthropology, Southern Methodist University, Dallas, Texas 75275, USA

$\dagger$ Egyptian Geological Survey, Cairo, Egypt

\$Institute of Archaeology and Ethnology, Polish Academy of Sciences, 00-140 Warsaw

The Sahara west of the Nile in southern Egypt was hyperarid and unoccupied during most of the Late Pleistocene epoch. About 11,000 years ago ${ }^{1}$ the summer monsoons of central Africa moved into Egypt, and temporary lakes or playas were formed. The Nabta Playa depression, which is one of the largest in southern Egypt, is a kidney-shaped basin of roughly $10 \mathrm{~km}$ by $7 \mathrm{~km}$ in $\operatorname{area}^{2-4}$. We report the discovery of megalithic alignments and stone circles next to locations of Middle and Late Neolithic communities at Nabta, which suggest the early development of a complex society. The southward shift of the monsoons in the Late Neolithic age rendered the area once again hyperarid and uninhabitable some 4,800 radiocarbon years before the present (years $\mathrm{BP}$ ). This well- determined date establishes that the ceremonial complex of Nabta, which has alignments to cardinal and solstitial directions, was a very early megalithic expression of ideology and astronomy. Five megalithic alignments within the playa deposits radiate outwards from megalithic structures, which may have been funerary structures. The organization of the megaliths suggests a symbolic geometry that integrated death, water, and the Sun. An exodus from the Nubian Desert at $\sim \mathbf{4 , 8 0 0}$ years BP may have stimulated social differentiation and cultural complexity in predynastic Upper Egypt.

Pastoralists seem to have entered the Nabta region (Fig. 1 inset) during the summer rainy season beginning $\sim 10,000$ years BP. Most of the early sites at Nabta consist of small concentrations of artefacts with one or more hearths, evidence of repeated summer occupation by small family groups. In addition to bones of gazelles, hares, jackals, and small mammals, most of the sites also contain bones of cattle, which may have been used for milk, blood, and transport ${ }^{5,6}$.

There were three major moist periods in the Holocene epoch in the Eastern Sahara, each of which is documented by massive silt deposits in the seasonal playas, for which we have over 100 radiocarbon dates ${ }^{7}$. These three playa episodes of the Early, Middle, and Late Neolithic ages were separated from each other by periods of hyperaridity, at 7,300-7,100 years $\mathrm{BP}$ and $6,700-6,500$ years $\mathrm{BP}$, when the water table was lowered to the same or lower levels than those of today. The preceding playa silts were extensively eroded and in some instances sand dunes filled the hollows. The alignments, megalithic structures and sandstone circles were placed in sediments that probably accumulated between 7,000 and 6,700 years $\mathrm{BP}$, at the end of the Middle Neolithic.

These Neolithic settlements reveal repeated occupation over several millennia during the summer rainy season, when there was enough water in the playas for large groups and their animals. At 8,100-8,000 years BP in the Early Neolithic, dates that are well established by a cluster of radiocarbon dates from charcoal and ostrich eggshells, larger communities appeared. One village (E-756) contained more than 18 houses, arranged in two (possibly three) straight lines, and deep walk-in wells, which required significant labour investment and control ${ }^{3,8}$. One well that we excavated was $4 \mathrm{~m}$ in width and $3 \mathrm{~m}$ deep; the existence of this well may have made it possible for some people to live in the desert throughout the year. The construction of the wells may be the first indication of emerging social control that later made the design and execution of the megalithic complex of the Late Neolithic possible.

Although primarily attracted to the playa for its water and forage, these nomadic groups must have engaged in a variety of activities during summer occupation, such as social bonding, marriage, trade, and ritual. The abundance of cattle remains in the Middle and Late Neolithic settlements is consistent with the ritual traditions of modern pastoralists, who may slaughter cattle to mark socially important events. We excavated two types of cattle tumuli at Nabta. The most common type consists of unshaped blocks of sandstone containing disarticulated bones of one or more cattle. One such tumulus (E-96-1) has yielded a date of 5,500 years вр \pm 160 years, from charcoal in a hearth. The second type of cattle tumulus (E-94-1), which may have marked a place and an event of considerable ideological significance for the group, consisted of an articulated skeleton of a young cow buried in a roofed, clay-lined chamber, which was covered with unshaped sandstone blocks. Wood from the roof of the chamber yielded a radiocarbon date of $6,470 \pm 270$ years $\mathrm{BP}$.

Oval clusters of large recumbent slabs constitute the megalithic structures (Fig. 1), which we initially thought might mark highstatus burials. However, no firm evidence of human burials was found in any of these features. Although churning clay vertisol would probably have destroyed all buried material except large rocks, the structures may have served primarily as proxy tombs for high-ranking individuals who died on the trail. Excavation and 